\title{
Média(technika)történeti episztemológia
}

\begin{abstract}
Absztrakt. A cikk a médiatudományok jelenlegi állapotának kritikai vizsgálatát kívánja nyújtani. Amellett érvel, hogy meg kell haladnunk Friedrich Kittler munkásságát, valamint megfogalmazza az olyan kortárs digitális technológiák feltárásának igényét, mint a hálózati számítógépes rendszerek és a fejlett felhasználói interfészek, amelyek a kittleri gondolkodás vakfoltjai.
\end{abstract}

„Meghalt a király, éljen a király!” Elnézve a különböző workshopokat és publikációkat, amelyek After Kittler és ehhez hasonló címeken futottak a közelmúltban, azt hihetné az ember, hogy a francia örökletes monarchia e jelmondata nem is áll távol a német médiatudósok újabb nemzedékétöl. $A$ bökkenő csak az, hogy itt a régi király és az új király ugyanaz: Friedrich A. Kittler. Márpedig ennek láttán elöször is fel kell tennünk a kérdést, vajon szerencsése a german media theory (Eva Horn) effajta megszemélyesítésének ez a tendenciája. Azzal a veszéllyel jár ugyanis, hogy egy lépéssel még közelebb kerül a sokszor szemlátomást éppen élősködő, a „klasszikus” tudományokkal szembenálló, kalózszerű létezése révén sikeres médiatudomány legalábbis kérdéses kanonizálódásához és szaktudománnyá válásához (és nemzetivé válásához?). Ennek a címnek valószínüleg csak ott van értelme, ahol a german media studies - egész tudatosan használom itt a többes számot - más elméletkultúrákba való átviteléről van szó. Példa lehet az utóbbira Bernhard Geoghegan történetesen After Kittler címmel megjelent folyóiratcikke, amelyben a berlini média- és kultúratudós a kultúrtechnika kutatásába (Cultural Techniques) nyújt bevezetést a Theory, Culture and Society hasábjain. ${ }^{1} \mathrm{~A}$ második kérdéses pont a médiumok anyagiságai iránti túlzott érdeklődés, amely a technikai médiumok lecsavarozott fedele alatt sejti a készülékek létét, és ott is akar rátalálni. Föleg érvényes ez akkor, amikor például Kittler időközben elhíresült szintetizátorán végzett forrasztópákás ügyködéséböl kiindulva lovallja bele valaki magát a techno-hermeneutikai tébolyba, amitől alighanem a király is forog a sírjában - ugyancsak magas fordulatszámon. Végül egy harmadik kifogás is felmerül az after Kittleről való beszéd értelmes voltát illetően, nevezetesen arra a helyzetre vonatkozólag, hogy a német médiatudomány jelentős berkeiben - a kultúrtechnika-kutatás és annak is föként a weimari irányzata csak egy a lehetséges példák közül - már jó tizenöt éve Kittlernek a

Ez az írás az IFK Wien kutatási ösztöndíjának keretében készült.

1 Bernard Geoghegan, After Kittler: On the Cultural Techniques of Recent German Media Theory, Theory, Culture and Society 30/6 (2013), 66-82. 
médiumok anyagiságára vonatkozó aprioriját igyekeznek kritikusan továbbgondolni, és réges-rég after Kittler módon müködnek.

Miközben teljesen helytálló az after Kittler-vita mellékzöngéjeként hallható diagnózis, mely szerint a mai digitális médiakultúrák olyan elméleti deficitben szenvednek, amelyet sehogy sem fedeznek Kittler technikai írásai. Még az olyan, jórészt az ő gondolkodásából - vagy az attól való részleges elhatárolódásból született tudományterületek, mint az episztemológiai érdeklődésű médiatörténet (Claus Pias, Stefan Rieger és mások), a médiaarcheológia (Wolfgang Ernst, Jussi Parikka és mások), a mediális historiográfiák (Joseph Vogl, Lorenz Engell) vagy a kultúrtechnika-kutatás (Bernhard Siegert, Claudia Visman, Markus Krajewski, Christian Kassung és mások), de az újabb médiaökológiákra (Erich Hörl, Mark N. B. Hansen) vagy az aktor-hálózat-, újabban pedig aktor-médiaelméletre (Bruno Latour, Erhard Schüttpelz és mások) vonatkozó megfontolások is csak ritkán mernek elrugaszkodni a digitális médiumok jelenébe. Ennek egyik oka lehet annak az affirmatív, a technika lázában égő, ám technikai vonatkozásokban és ismeretekben cseppet sem bővelkedő diskurzusnak a tartósan riasztó példája, amely az 1990-es évek végén folyt a digitalitásról, a kialakuló onlinekultúráról és a virtuális valóságról. Egy további ok minden bizonnyal abban rejlik, hogy a korai 1980-as évek számítástechnikájára alapozott kittleri gondolkodás nem vett tudomást olyan témákról, mint a hálózatba kapcsolt és felhasználóbarát otthoni számítógépek vagy az objektumorientált programozás. Csakhogy aztán Kittler lestrapált diktumát, mely szerint szoftver nem létezik, egykettőre elszipkázta a sürgősen esedékes hálózat-diskurzus (Alexander Galloway, Eugene Thacker és mások), és mielőtt észbe kaphatott volna az ember, a szoftver máris kezdte átvenni a parancsnokságot (Lev Manovics, Matthew Fuller és mások).

Mindezek láttán nekifogni a kittleri életmű komplett dekonstrukciójának éppúgy rövidlátásra vallana, mint a fent említett kvázi-hermeneutikai interpretációk. Azt viszont roppant izgalmas volna feltárni, hogyan lehet a kittleri médiaelméleteket átvinni a mai digitális kultúrákra - amiben jómagam szívesebben követném Kittler „technikai írásainak” gesztusát, mint késői felszólalásait a görög matematikáról. Emellett az a kérdés is felvethető, hogyan alkalmazhatnánk „a technikai apriori aprioriját” (Geoghegan), ahogy az a kultúrtechnika-kutatásban megfogalmazódott, napjaink digitális technikáira - erre tettem kísérletet az említett Theory, Culture and Society-számban, mégpedig a kultúrtechnikának tekintett komputerszimuláció példáján. De elsősorban azt kellene megnézni, meddig jutottak mindezek továbbgondolásában a föként angol-amerikai illetőségủ new media-elméletek - nem ritkán Kittlerre hivatkozva vagy éppen elhatárolódva tőle -, valamint azt, hogy mi magunk menynyiben tudjuk ezeket az ajánlatokat a technikai anyagiságokon és azok történeti-episztemológiai genealógiáin iskolázott és ezekben érdekelt german media theories segítségével tovább élesíteni és konkretizálni. Úgy értem, hogy olyan példaszerü, mediális-materiális tárgyterületekre kellene összpontosítani, amelyek mélyebbre hatolnak, mint az általában felhozott filmpéldák, mondjuk a data mining és a „megelőző cselekvés” kontextusában unos-untalan citált Különvélemény vagy a médiaelmélet újraantropologizálásának irányába végrehajtott puszta rollback (például Mark N. B. Hansen).

Valószínüleg tényleg nem lehet elégszer elismételni, hogy médiatechnikai helyzetünk mindenekelőtt újabb és újabb fejtörőt jelent. Olyan fejtörőt, amelyhez sosem árt erőt meríteni specifikus és konkrét médiatechnikákból és genealógiá- 
ikból, tematikus kutatási kontextusokból és praxeológiai vonatkozásokból. Más szavakkal: olyan fejtörőt, amely (digitális) médiumoknak (médiatechnikáknak) szentelt transzdiszciplináris esettanulmányokban találja meg az alapozásait, amelyekből aztán elméleti levezetések vagy, ha úgy tetszik, akár médiaelméletek jönnek létre. Ebből a perspektívából nem merül fel a kérdés, hogy az adott esetben mi a médium vagy mi mediális; ebben a perspektívában a mindenkori specifikus müködés és processzálás kap figyelmet, az eszközök vagy technológiák „médiummá válása” (Vogl) kerül a középpontba. Ha az efféle médiatudományi megközelítésmód eleve kapcsolatban áll a szomszédos tudományágakkal, úgymint irodalom- és történettudomány, tudománykutatás, szociológia, filozófia és képtudomány, a digitális médiumok tekintetében még inkább bele kellene bocsátkoznia az informatikába, a matematikába és további természet-, illetve mérnöki tudományokba, hogy aztán tudásukat a maga médiatudományos aspektusaiból próbálja összekapcsolni és újrafogalmazni.

A médiatudományos keresztkérdezés semmihez sem fogható luxusa abban rejlik - legalábbis az én szemszögemböl -, hogy egy-egy konkrét „tárgy” segítségével, például a rajkutatás történetéböl, elméleti aspektusok dolgozhatók $\mathrm{ki}^{2} \mathrm{Az}$ én esetemben a zavar médiaelméletéhez vagy a médiumok zavarelméletéhez kapcsolódó munkáról volt szó, melynek az adta operatív jelentőségét, hogy egy konkrét tárgyat, egy mediális-materiális „zavaró tényezőt" vett górcső alá, és rajta keresztül körvonalazott messzebbre mutató elméleti aspektusokat. lly módon azzal is meg lehet próbálkozni - itt is a saját kutatásaim összefüggéséből veszem a példát -, hogy az ágens alapú komputerszimuláció médiatörténetéből kiindulva olyan nagyelméletek lehetőségfeltételeit keressük e szimulációk genealógiájában, mint az aktor-hálózat-elmélet. Meg lehet kísérelni a laboratory studiesból vett fogalmak (például a Hans-Jörg Rheinberger-féle „episztemológiai dolog”) újrafogalmazását a tudományban használt digitális médiumok jegyében, vagy rá lehet kérdezni azokra a szocioökonómiai mozzanatokra és modellálásokra, amelyek egyáltalán kézenfekvővé tették az „ágens-társadalmakban” való gondolkodást. A médiumelmélet így maga is mediális hatásnak mutatkozik. Ezzel pedig, a példaként szolgáló esetben, többletértékre tehetünk szert mondjuk a számítógépes szimuláció olyan hagyományos filozófiáival (Manuel DeLanda és mások) vagy episztemológiáival (Eric Winsberg, Paul Humphreys és mások) szemben, amelyek újfent csak aktuális médiatechnikai kapcsolódások nélkül íródtak.

Ezzel analóg módon más médiatechnikákból kiindulva is egészen hasonló digitalitás-elméletek dolgozhatók ki, melyekre minden esetben egy-egy konkrét technikai környezet, egy-egy eset ad alkalmat. Mindezt kiegészíthetné a meglevő konvenciókkal és elméletekkel való szembeállítás - amennyiben például a big data mai kontextusában újra kell gondolni az „adat” vagy az „empíria” fogalmait és koncepcióit. Ez pedig átvezetne azokhoz a részelméletekhez, amelyek leírják, hogy miként határozzák meg helyzetünket a digitális médiumok a mindenkori technikai megalkotottságuknak, intézményi kontextusuknak és használati módjuknak megfelelően, vagyis hogy miként hatják át a megismerés, ábrázolás és kutatás lehetőségeit, mindegyik a maga specifikus módján. Ezek a részlegességek - remélhetőleg - sosem vonhatók majd össze egyetlen, megszilárduló

2 Sebastian VEHLKEN, Zootechnologien. Eine Mediengeschichte der Schwarmforschung, Berlin - Zürich: Diaphanes, 2012. 
médiaelméleti építménnyé. A médiatudománynak elsősorban meg kellene maradnia a Ludwik Fleck-i értelemben vett gondolkodási stílusnak vagy gondolkodási együttműködésnek, amely rendre esetről-esetre bomlik ki.

Mindezt másként is lehet látni, és ez a cikk sem tehet többet, mint hogy további vitákra ösztönöz. Ezzel együtt sem mellözhető a digitalitás médiatudományos feldolgozásával kapcsolatos néhány, vélhetőleg szubkután, szabadon lebegő, egyelöre megoldatlan metodológiai kérdés egészen pragmatikus megfogalmazása. A digitalitás „alszínein” (Frieder Nake) kezdődnek - és talán a következőképp hangzanak:

(1) Médiatudósként hogyan közelíthetek egyáltalán nagy komplexitású, például az algoritmikusan szervezett adatlehívási eljárások területéről vett technikai összefüggésekhez mint kutatásom tárgyához?

(2) Hogyan tudakozódom az informatika és a természettudományok szakértőinél, ha például a komputerszimulációs rendszereikről olyasvalamit akarok megtudni, ami hiányzik a leírásaikból?

(3) Meddig menjek el aktualizálás dolgában, ha a technikai fejlődés mai tempója mellett a Facebookról írt okosabb cikkek is már a megjelenésükkor idejétmúltak, három év alatt pedig tökéletesen érvényüket vesztik, mert a hálózatot utoléri a MySpace-halál?

(4) Vajon csak akkor ragadhatom meg a big data jelenségét, ha - mint például a berlini MPIWG-ben felállított Historicizing Big Data munkacsoport - sokadszorra is visszapillantok a 19. századba? Vagy éppen hogy akkor nem sikerül?

(5) Az anyagiság kittleri (és újabban Wolfgang Ernst-i), hands-on megközelítésének analógiájára: Hány programkódot kell (tudnom) olvasni, ha software studiesra adom a fejem? Mit jelent az ilyen szövegek kritikus olvasása?

(6) Hogyan viselkednek az új digitális módszerek (mondjuk a digital humanities kiértékelési eszközei) a digitális médiumok elméleti meghatározásának tekintetében? Elemi alkotórészét alkotják ennek a tudománykultúrának, vagy nélkülük is boldogulok? Mi a biztosíték, hogy kritikusan, nem pozitivista módon kezelem az eredményeit?

(7) Végül egy nagyon is Foucault-i kérdés: hányadán is állunk saját episzteménk leírhatóságának lehetőségével?

Ezekkel a kérdésekkel föleg azok a kultúratudományos módszerekkel dolgozó harmadik generációs médiatudósok szembesülnek, akik már intézményes környezetben tanulhattak „valami médiával kapcsolatosat” és kezdhették meg tudományos pályafutásukat, médiaelméleti szemináriumaik pedig, ahogy maga Kittler mondta egyszer, inkább illenének be a Club Mediterranée felkészítő táborainak. Az ő nemzedékükről írta egyszer Claus Pias: ezeknek az embereknek megvan az a szabadságuk, hogy olyasmiket tegyenek, amiknek „semmi másban nem rejlik az értelmük, mint hogy megteszik őket - a kalandos érzésben, hogy nadrágba tűzött pisztolyt hordanak, gyors autókat vezetnek, bankokat rabolnak, és gyönyörü nőkkel veszik körül magukat". ${ }^{3}$ Izgalmas lesz látni, hogyan ránt revolvert a Kittler-unokák nemzedéke - azt meg még inkább, hogy hová céloz.

Fordította Fenyves Miklós

3 Claus PIAS, Was waren Medien-Wissenschaften? Stichworte zu einer Standortbestimmung $=$ Uö, Was waren Medien?, Berlin - Zürich: Diaphanes 2010, 11. 


\section{Irodalom}

Geoghegan, Bernard, After Kittler: On the Cultural Techniques of Recent German Media Theory, Theory, Culture and Society 30/6 (2013), 66-82.

PIAS, Claus, Was waren Medien-Wissenschaften? Stichworte zu einer Standortbestimmung = Uö, Was waren Medien?, Berlin - Zürich: Diaphanes 2010.

VEHLKEN, Sebastian, Zootechnologien. Eine Mediengeschichte der Schwarmforschung, Berlin - Zürich: Diaphanes, 2012.

\section{Historical Epistemology of Media(Technology)}

This article presents a critical inquiry into the current state of media studies. It argues that it is necessary to go beyond the work of Friedrich Kittler, and calls for an exploration of contemporary digital technologies such as networked computer systems and advanced user interfaces - something which constitutes a blind spot in Kittler's thinking.

Keywords: digital culture, Friedrich Kittler, media theory, media archaeology

Sebastian Vehlken, Dr.

a „Számítógépes szimuláció médiakultúrái” c. DFG-kutatócsoport junior igazgatója (Leuphana Universität Lüneburg), jelenleg az IFK Wien ösztöndijasa

sebastian.vehlken@leuphana.de 
